\title{
Зовнішня антибактеріальна терапія: сучасні можливості лікування
}

\author{
Я.Ф. Кутасевич, С.К. Джораєва, О.І. Олійник, Г.М. Біляев \\ ДУ «Інститут дерматології та венерології НАМН України»
}

\begin{abstract}
Резюме
Мета роботи - викласти принципи і поліпшити антибіотикотерапію піококових інфекцій шкіри і м'яких тканин.

Матеріали та методи. У дослідження були включені 52 пацієнти з тяжкими і поширеними дерматозами, які перебували на стаціонарному лікуванні в дерматологічному відділенні ДУ «ДВ НАМН України». Ідентифікацію аеробних грампозитивних, аеробних грамнегативних ферментуючих і неферментуючих бактерій, виділених з різних ділянок шкіри, проводили за допомогою рутинних методів на підставі морфологічних, культуральних і біохімічних властивостей збудників.

Результати та обговорення. У результаті бактеріологічного дослідження було виділено 59 штамів мікроорганізмів від пацієнтів. Домінували мікроорганізми роду Staphylococcus, що обтяжували перебіг дерматозів. 3 метою підвищення терапевтичної ефективності та нормалізації мікробіоценозу хворих на хронічні дерматози у лікуванні використовували зовнішню терапію, що включала мазь мупіроцину. У результаті використання зазначеної схеми зовнішнього лікування хворих на тяжкі хронічні алергічні дерматози в період загострення відзначено регрес клінічних ознак піококових інфекцій у 94,2\% пацієнтів. Клінічну ремісію досягнуто у 28,9\% хворих, значне поліпшення - у 53,9\%, поліпшення - у 11,4\%.

Висновки. Вивчено можливості використання топічних антибактеріальних засобів, механізм дії, фармакокінетику і доцільність застосування мупіроцину в практиці лікаря-дерматолога, що дозволяє рекомендувати мупіроцин для лікування пацієнтів із хронічними дерматозами, які тривалий час отримували імуносупресивну терапію.

Ключові слова: зовнішня терапія, антибактеріальна терапія, мупіроцин.
\end{abstract}

DOI: 10.33743/ 2308-1066-2019-3-24-30

\section{Вступ}

Серед усіх дерматозів піодермії превалюють над іншими шкірними хворобами: так, за даними ВООЗ, поширеність піодермій у розвинених країнах становить $1 / 3$ від інфекційних захворювань. Піодермії - група поширених інфекційних захворювань шкіри, які характеризуються рецидивним перебігом і часто потребують складної тривалої терапії. Актуальність проблеми й необхідність пошуку нових підходів до лікування обумовлені широким поширенням збудників патогенної та умовно-патогенної інфекції, активною участю мікробів в імунних і неімунних механізмах запалення шкіри, а також зростаючою частотою множинних резистентних до етіотропного лікування збудників і нераціональною антибіотикотерапією.

Як відомо, патогенна та умовно-патогенна бактеріальна інфекція може ускладнювати перебіг дерматозів неінфекційного походження. Порушення мікробіоценозу шкіри є фактором, що сприяє розвитку запального процесу у вогнищах патології [1]. Натепер можемо спостерігати зміну біологічних властивостей збудників бактеріальних інфекцій шкіри, що пов’язано з безконтрольним застосуванням антибактеріальних препаратів, збільшенням кількості полірезистентних штамів основних збудників цієї патології, розширенням спектра ̈іх стійкості до протимікробних препаратів, а також виникненням змінених і $\beta$-лактамазопродукуючих штамів.

Запальні захворювання шкіри та м'яких тканин є провідним інфекційним фактором: фолікуліт, фурункул, імпетиго, абсцес, стрептостафілодермія, сикоз, акне тощо; також бактеріальні ускладнення можуть розвиватися на тлі дерматозів неінфекційної природи: алергодерматози, лімфопроліферативні захворювання, псоріаз, мікози стоп, епідермодерміт, короста, трофічні виразки, розацеа. Клінічна картина зазначених захворювань представлена на рисунках 1-4.

Основними чинниками розвитку бактеріальних інфекцій шкіри та виникнення ускладнень інших дерматозів є патогенні (транзиторні) стрептококи - 5\%, патогенні (транзиторні) стафілококи - 17\%, умовно-патогенні (резидентні) дифтероїди, мікрококи - 51\% і змішана мікрофлора - 27\% випадків [24]. Джерелами інфекції можуть бути сапрофіти шкірного мікробіоценозу, ендогенні мікробні резервуари організму й агенти зовнішнього середовища.

Фактори, що призводять до розвитку бактеріальних інфекцій, можна розділити на:

- місцеві - пошкодження рогового шару, підшкірної жирової клітковини і зміна рН;

- системні - зниження загальної резистентності організму, обмінні захворювання, вікові фактори, розлади потовидільної та терморегулюючої функції шкіри, а також нестача ензиматичних факторів.

Причинами розвитку бактеріальних ускладнень неінфекційних захворювань шкіри можуть бути порушення цілісності шкіри та функції шкірного бар'єра, особливості біоценозу шкіри при різних дерматозах, зниження 


\section{КЛІНІЧНІ СПОСТЕРЕЖЕННЯ}

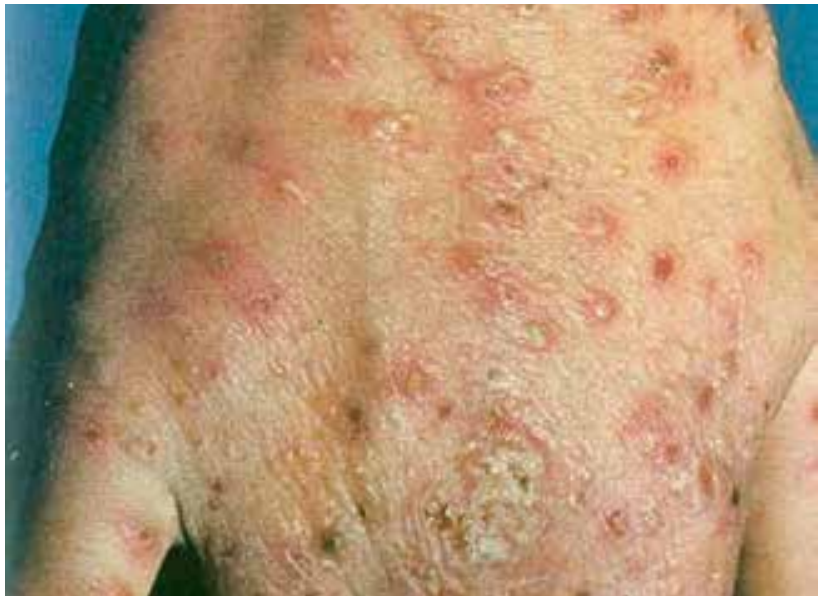

Рис. 1. Фолікуліт

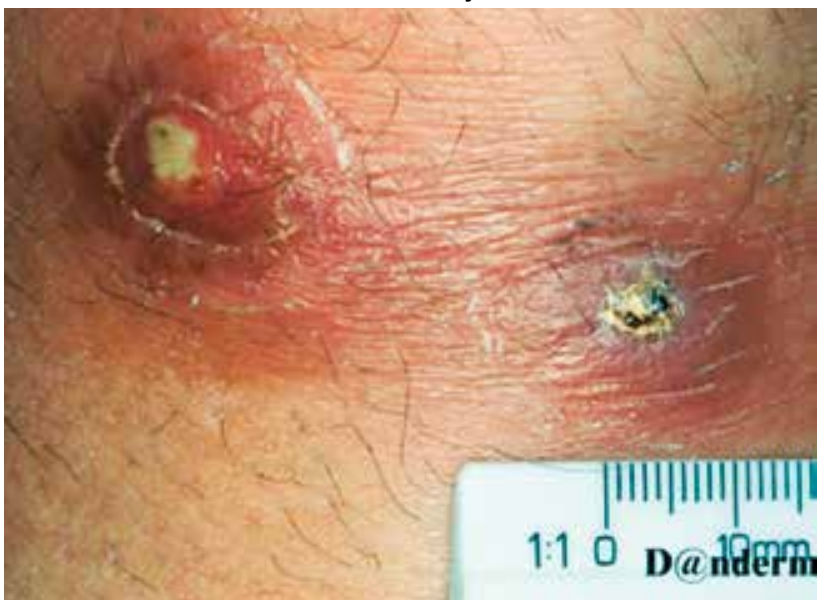

Рис. 2. Фурункули

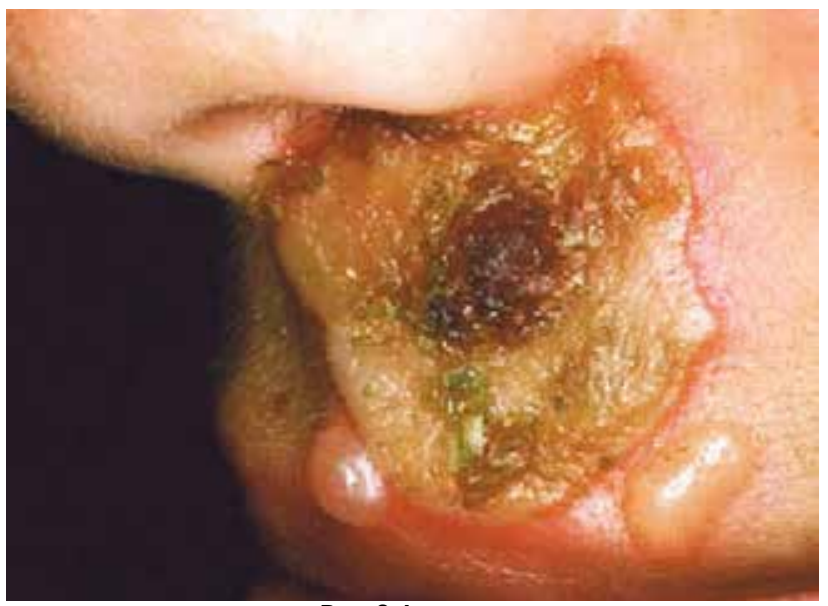

Рис. 3. Імпетиго

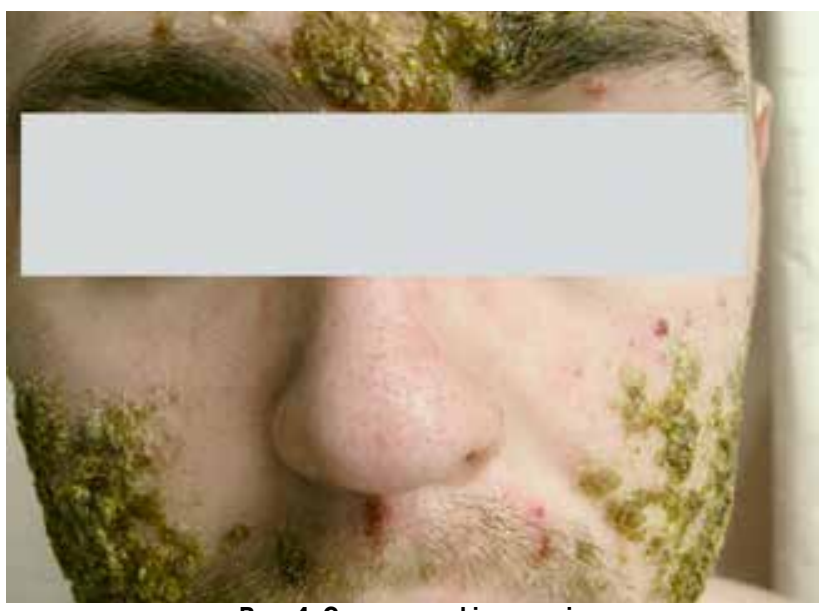

Рис. 4. Стрептостафілодермія імунітету, цукровий діабет, тяжкі виснажливі захворювання, дитячий або похилий вік тощо. Порушення вуглеводного обміну також відносять до причин розвитку бактеріальних ускладнень [2, 3].

Мікробний пейзаж у хворих на екзему істотно відрізняється від мікробіоценозу шкіри здорових осіб як якісно, так і кількісно (виявляють до 22 видів мікроорганізмів). Так, у хворих на атопічний дерматит обсіменіння патогенною і умовно-патогенною мікрофлорою втричі вище, ніж у пацінтів з екземою [4]. Ускладнення піококовою інфекцією у хворих на алергодерматози не завжди супроводжується пустулізацією, прояви можуть характеризуватися посиленням клінічних ознак загострення.

У хворих з мікотичним ураженням стоп, ускладненим піодермією (приєднанням вторинної інфекції; бактеріальний целюліт), виникає мікробна екзема. Целюліт гостре дифузне запалення м’яких тканин, що характеризується гіперемією і набряком без нагноєння і некрозу. Бактеріальний целюліт - група захворювань, до яких належить бешиха та глибші процеси без притаманних для бешихи чітких меж i «язиків полум'я». Мікози стоп і оніхомікози розглядають як процеси, що створюють вхідні ворота для бактеріальної інфекції, їх виявляють у 80\% пацієнтів з целюлітом, які не можна пояснити іншими причинами. Найбільший ризик розвитку бактеріального целюліту мають пацієнти з порушенням цілісності шкірних покривів, мікозом стоп, ожирінням, цукровим діабетом, хронічним набряком кінцівок, а також особи з бактеріальним целюлітом в анамнезі.

У боротьбі з бактеріальними інфекціями шкіри та інфекційними ускладненнями неінфекційних дерматозів застосування зовнішніх засобів лікування має низку переваг: це унікальна можливість безпосереднього впливу на вогнище ураження, що забезпечує максимальний інтенсивний вплив препарату безпосередньо в осередку ураження при незначній системній дії, що зводить до мінімуму побічні ефекти терапії. У разі лікування засобами зовнішньої терапії можна використовувати препарати різного механізму дії, що забезпечує динамічність лікування [2].

Дотепер є актуальною розробка топічного антибактеріального засобу, який би не використовувався системно і не мав би хімічної спорідненості з системними антибіотиками. У 1867 р. вперше при відкритому переломі кістки з лікувальною метою була застосована аплікація карболової кислоти. У 1887 р. була виявлена антимікробна активність Pseudomonas fluorescens, і тільки в 60-х роках XX століття була виділена й очищена з культури NCIB10586 монокарбохінова кислота, названа псевдомонієвою. Суміш кількох метаболітів з подібною хімічною структурою та антимікробним спектром отримала назву Pseudomonaceae, а британський фармакопейний комітет і ВООЗ дали отриманій речовині генеричну назву мупіроцин [22].

Мупіроцин - це місцевий антибіотик, який представляє власну фармакологічну групу антимікробних засобів. Він є продуктом ферментації сапрофітних мікроорганізмів виду P. fluorescens і представлений декількома активними метаболітами, серед яких 90-95\% становить псевдомонієва кислота А [21]. Препарат має унікальну хімічну будову та механізм дії, які вирізняють його з усіх інших відомих антимікробних речовин, 


\section{КЛІНІЧНІ СПОСТЕРЕЖЕННЯ}

він містить бічний ланцюг з короткої жирної кислоти, з'єднаної ефірним зв'язком 3 монієвою кислотою. Термінальна частина молекули монієвої кислоти дуже подібна за структурою до амінокислоти ізолейцину [10].

Мупіроцин, зв'язуючись 3 ферментом ізолейцил-тРНК-синтетазою (IC), блокує утворення з відповідної амінокислоти і тРНК комплексу ізолейцил-тРНК. Таким чином, антибактеріальна дія препарату полягає в порушенні синтезу РНК і білків у клітинах бактерій $[16,17]$. Нещодавно було показано, що мупіроцин зв'язується з ІС поблизу АТФзв'язувальної ділянки. На підставі цього зроблено припущення, що мупіроцин має структурну схожість як з ізолейцином, так і з АТФ, будучи аналогом ізолейциладенілату. У низьких концентраціях мупіроцин демонструє бактеріостатичну дію, близьку до мінімальної інгібуючої концентрації (МІК). У разі місцевого застосування впродовж 24-36 год в результаті створення дуже високої концентрації (20000 мг/л) препарат забезпечує бактерицидний ефект.

Мупіроцин in vitro демонструє високу активність щодо Staphylococcus aureus, у тому числі метицилінорезистентних (MRSA) і штамів, стійких до інших антимікробних препаратів (аміноглікозидів, макролідів, лінкозамідів, фузидієвої кислоти, хлорамфеніколу) [6, 9], а також стрептококів; водночас він має низьку активність in vitro проти представників нормальної мікрофлори шкіри, що є важливою особливістю препарату. Дотепер не описано перехресної резистентності мупіроцину з іншими антимікробними препаратами.

Важливими фармакокінетичними властивостями мупіроцину є здатність добре проникати в поверхневі шари шкіри та слизової носа, де препарат тривалий час зберігається, створюючи високі та стабільні концентрації, практично не абсорбуючись з поверхні неушкодженої шкіри (0,24\% за 24 год); абсорбція через слизову оболонку носа становить 1,2-5,1\% від дози. Однак ступінь всмоктування препарату може збільшуватися за наявності пошкоджень.

Мупіроцин може зазнавати часткового метаболізму в шкірному покриві (до 3\%) з утворенням монієвої кислоти, що не має антибактеріальної активності. Після прийому всередину або внутрішньовенного введення також перетворюється на неактивну монієву кислоту, яка швидко виводиться переважно з сечею $\left(\mathrm{T}_{1 / 2}-30\right.$ хв) [6]. Мупіроцин добре зв'язується

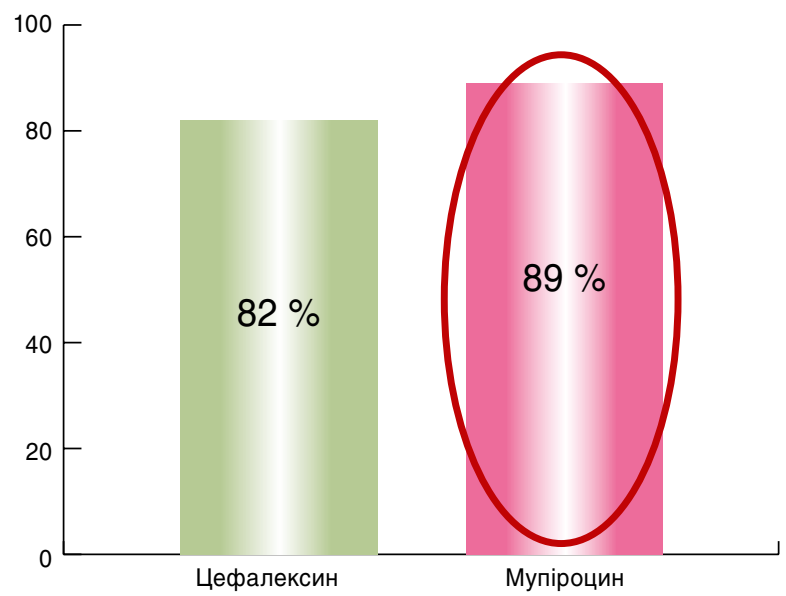

3 різними рідинами в організмі (кров, сироватка, гній). Дослідження in vitro визначили, що активність мупіроцину збільшується зі зниженням рН середовища, що є перевагою, враховуючи низькі значення $\mathrm{pH}$ шкіри. При $\mathrm{pH}=6$ активність мупіроцину в 4-8 разів вища, ніж при $\mathrm{pH}=7$ [9].

Показання до застосування мупіроцину:

- місцеве лікування первинних інфекцій шкіри (імпетиго, фолікуліт, фурункул, ектіма та ін.);

- вторинно інфіковані дерматози;

- ерадикація носійства в носовій порожнині та на шкірі $S$. aureus, у тому числі MRSA;

- профілактика катетер-асоційованої інфекції.

Аналіз терапевтичної ефективності мупіроцину (n = 24 - 1391) показав, що клінічна ефективність була досягнута у 81-100\% хворих, а елімінацію збудника спостерігали в 67-100\% пацієнтів [8]. Бактеріологічні та клінічні ефекти мупіроцину у формі мазі значно перевищували такі поліетиленгліколевої основи [11]. Також було продемонстровано, що мупіроцин перевершує багато антимікробних препаратів, що їх використовують місцево для лікування імпетиго (неоміцин, бацитрацин, фузидієва кислота, поліміксин В, хлортетрациклін) [8, 18]; а за даними низки авторів, мупіроцин не поступається [20] або навіть перевершує за ефективністю окремі пероральні антибіотики (еритроміцин, ампіцилін, цефалексин) [7, 12, 15].

Проведені численні дослідження щодо вивчення терапевтичної ефективності мупіроцину та інших антибактеріальних засобів для зовнішнього застосування [13, 14, 19], а також доведено переваги мупіроцину відносно клінічної та бактеріологічної ефективності у порівнянні з цефалексином (рис. 5) [7].

Препарат зарекомендував себе як ефективний щодо профілактики катетер-асоційованих інфекцій. Так, використання мупіроцину на додаток до стандартної схеми догляду за катетером в 4,5 раза знижувало частоту колонізації катетера (з 14,27 до 3,17 на 1000 пацієнтів на день) [23].

Зменшувався ризик розвитку:

- місцевих інфекцій з 23,9\% у контрольній групі до $4,3 \%$;

- бактеріємій, спричинених S. aureus, з 8,92 пацієнтів/ день до 0,71 на 1000 пацієнтів/день;

- час використання катетера зростав з 20 до 37 днів.

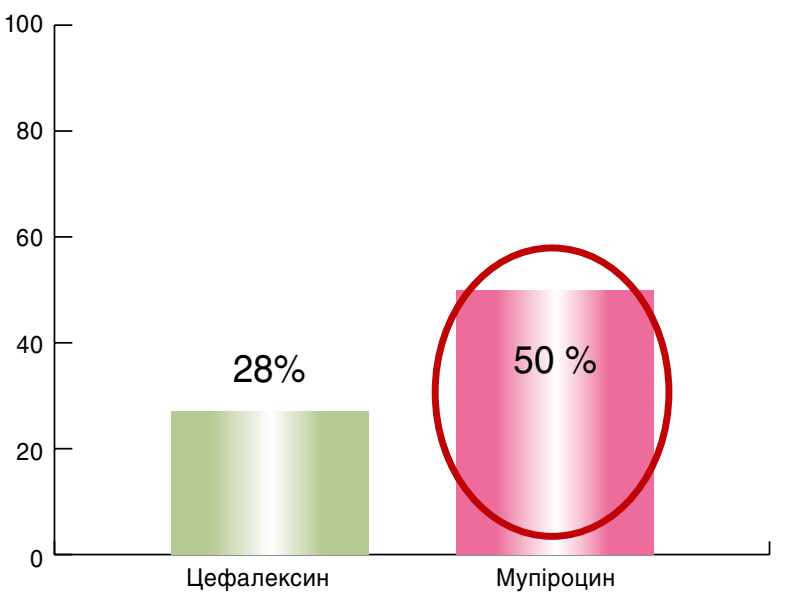

Рис. 5. Порівняння клінічної (а) та бактеріологічної (б) ефективності мупіроцину та цефалексину 


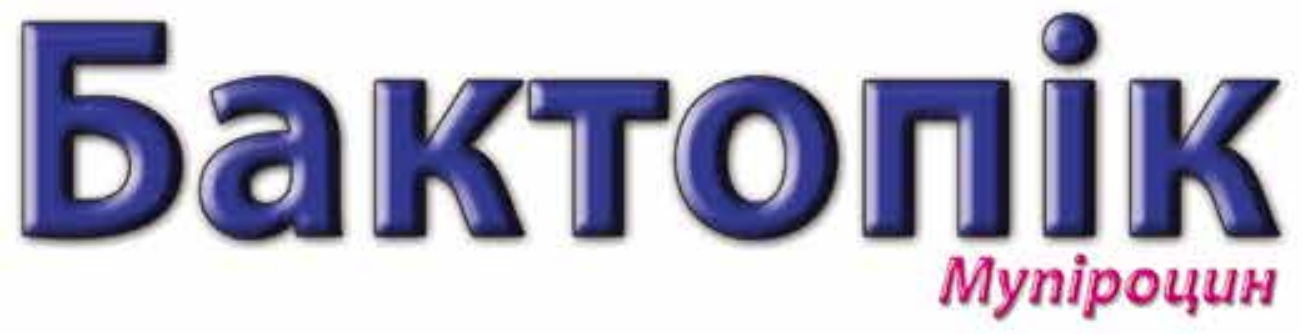

\section{подвійна сила' для ефективної і безпечної² ЕМпІРИЧнОї терапії інфекцій шкіри у дорослих та дітей 32 місяців! ${ }^{3}$}

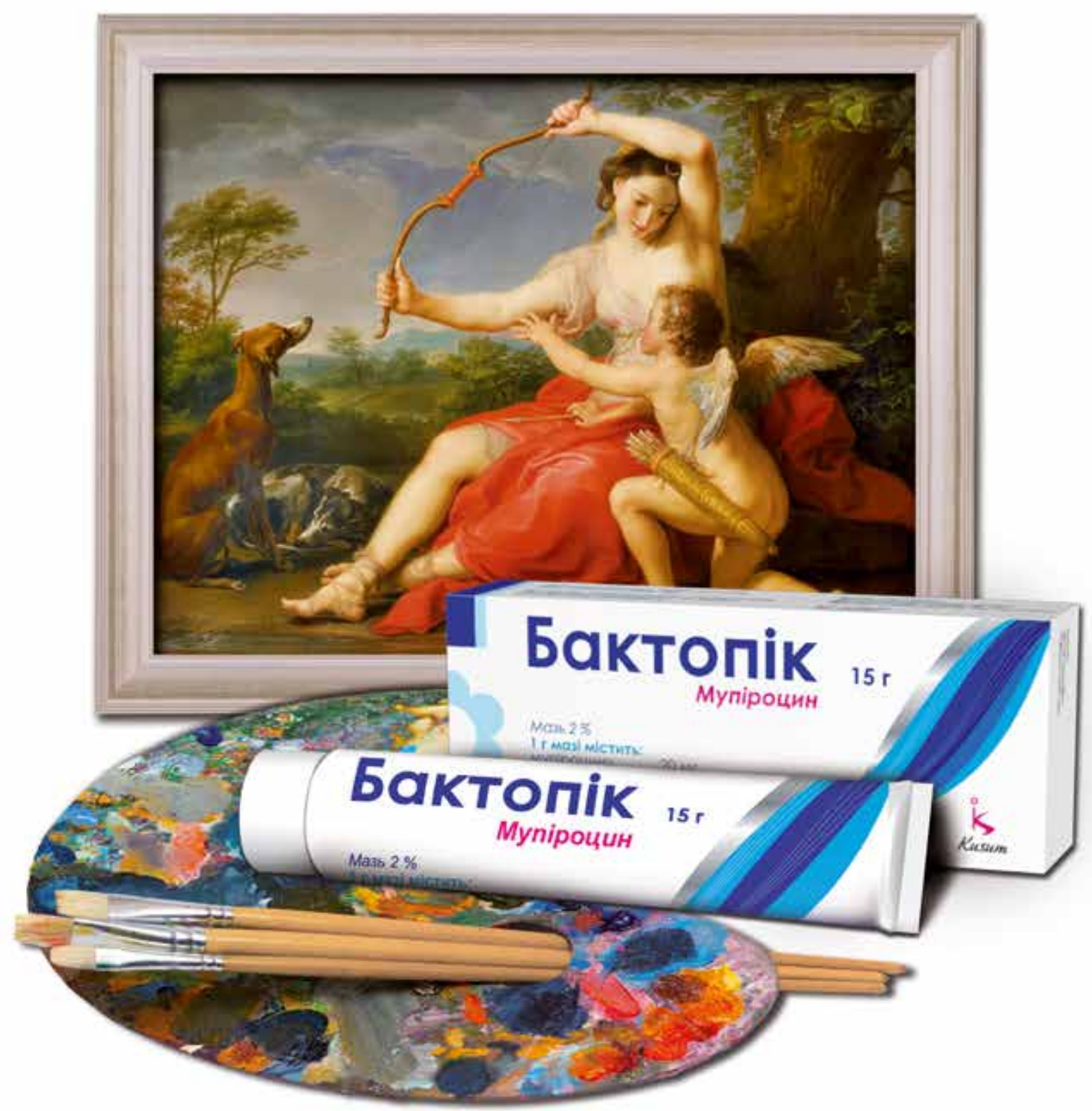

\section{Бактопік - художник чистої шкіри!}

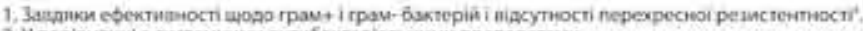

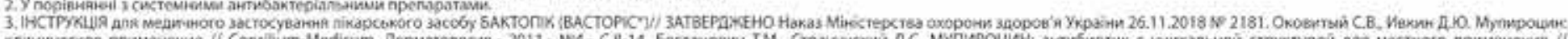

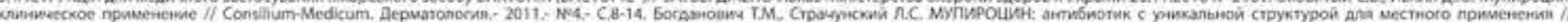

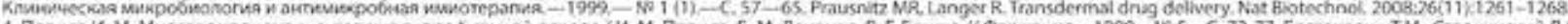

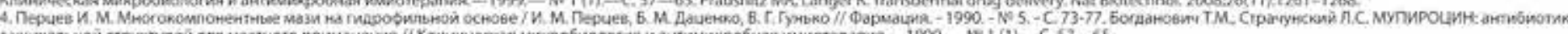

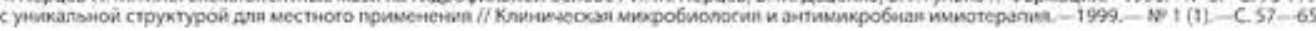

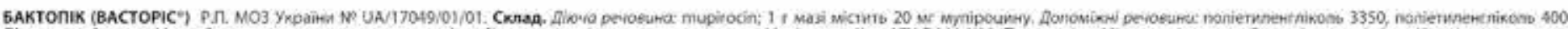

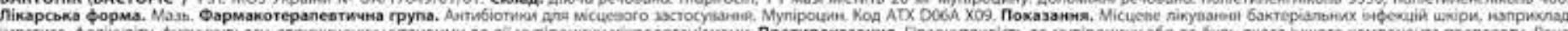

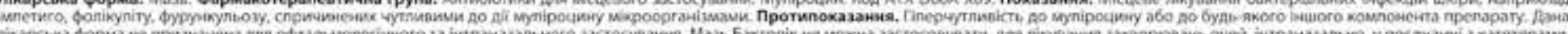

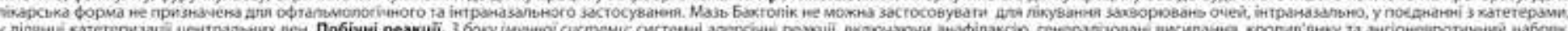

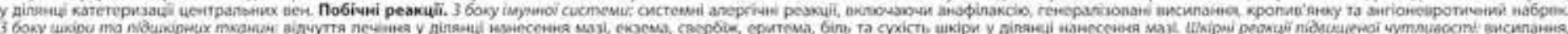

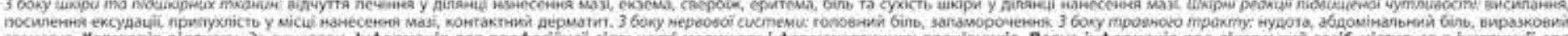

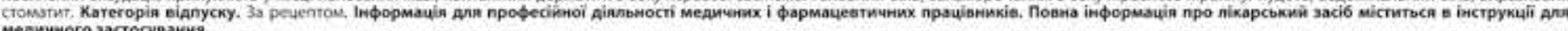
медичного застосуваненя. 


\section{КЛІНІЧНІ СПОСТЕРЕЖЕННЯ}

Мупіроцин демонструє хороший профіль безпеки: за даними різних досліджень, частота побічних ефектів від застосування препарату не перевищувала $2-3 \%$ (максимум $-7 \%$ ), вони були представлені контактним дерматитом, свербежем, печінням, болісністю та почервонінням шкіри. Як правило, відмова від застосування препарату не була потрібною [23].

\section{Матеріали та методи дослідження}

У дослідженні взяли участь 52 пацієнти з тяжкими та поширеними дерматозами, що знаходились на стаціонарному лікуванні в дерматологічному відділенні ДУ «ІДВ НАМН України» і отримували тривалу імуносупресивну терапію (в тому числі системну кортикостероїдну терапію та цитостатики). Контрольну групу становили 15 волонтерів відповідного віку та статі.

Матеріал для дослідження брали з уражених ділянок шкіри передпліч, внутрішньої поверхні стегон, грудної клітки, живота, спини, обличчя тощо. Ідентифікацію аеробних грампозитивних і грамнегативних ферментуючих і неферментуючих бактерій, вилучених з різних ділянок шкіри, проводили за допомогою рутинних методів на підставі морфологічних, культуральних і біохімічних властивостей [5].

Контроль якості визначення чутливості мікроорганізмів до антибіотиків, а також використовуваних реагентів (поживні середовища та диски з антибіотиками) проводили із застосуванням контрольних штамів Американської колекції типових культур (ATCC): $S$. aureus ATCC 25923, E. coli ATCC 25922, P. aeruginosa ATCC 27853, E. faecalis ATCC 29212.

Матеріал з вогнища та контрольної ділянки засівали на поживні та диференційно-діагностичні середовища (простий агар, кров'яний агар, агар Чистовича, сироватково-телуритовий агар, середовище Ендо, агар з метиленовим синім та ін.). Досліджуючи мікрофлору шкіри, враховували: загальне бактеріальне обсіменіння, наявність у вогнищі дослідження грампозитивних коків родин Streptococcaceae, Staphylococcaceae та Micrococcaceae, коринебактерій і грамнегативних мікроорганізмів (ентеробактерії, псевдомонади).

\section{Результати та їх обговорення}

У ході дослідження було продемонстровано, що в пацієнтів з хронічніми дерматозами переважали стафілококи над іншою мікрофлорою. У результаті бактеріологічних досліджень було вилучено 59 штамів мікроорганізмів від пацієнтів та 40 штамів від практично здорових людей. У посіві з вогнища в усіх пацієнтів домінували мікроорганізми роду Staphylococcus (38 штамів - 64,4\%), а саме: S. aureus (35,5\%), S. haemolyticus (22,6\%), S. epidermidis (16,1\%), S. warneri (12,9\%), S. cohnii $(6,5 \%)$ та $S$. saprophyticus $(6,5 \%)$. Крім того, представники роду Staphylococcus утворювали асоціації 3 Corynebacterium spp., Micrococcus spp. i Streptococcus spp. Ступінь загального мікробного обсіменіння коливався від $<1 \times 10^{3}$ до $1 \times 10^{7}$ КУО/мл. На рисунку 6 наведено розподіл різновидів стафілококів, вилучених з осередків ураження хворих на поширені дерматози, що отримували тривалу імуносупресивну терапію.

Частіше за все 3 осередку ураження вилучали 2 мікроорганізми (асоціація різних видів стафілококів визначалась у 17 осіб (39,5\%), стрептококів

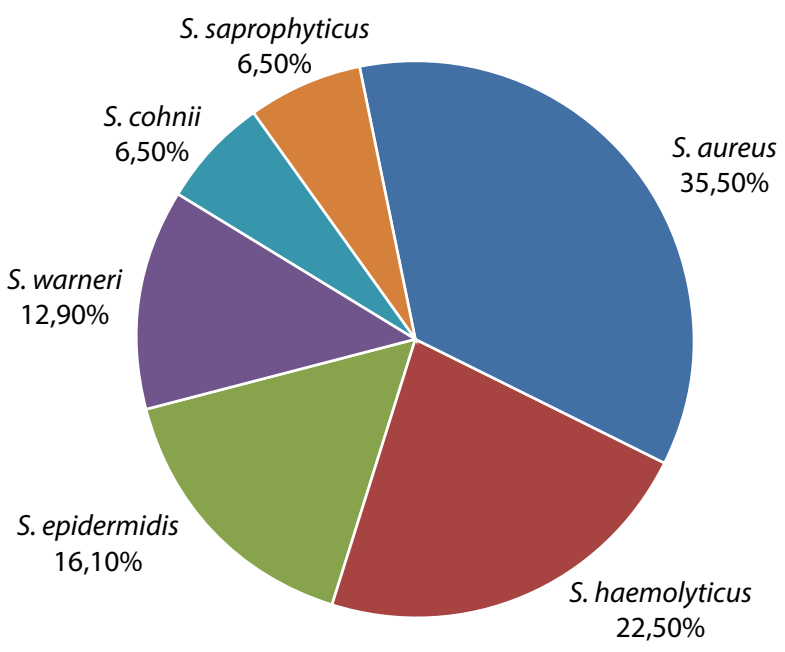

Рис. 6. Видовий розподіл стафілококів, вилучених від хворих на поширені дерматози, що отримували тривалу імуносупресивну терапію

зі стафілококами - у 7 (16,2\%), стафілококів з мікрококами або коринебактеріями - в 10 (по 11,6\%) і мікрококів з коринебактеріями - у 2 осіб (4,6\% випадків). Мікробний склад контрольної групи був представлений стафілококами і складався зі S. epidermidis (82,5\%), S. haemolyticus (5,0\%), S. aureus $(2,5 \%)$ та інших $(10,0 \%)$.

Результати аналізу досліджених властивостей лабораторних штамів стафілококів (S. aureus i S. haemolyticus) показали, що наявність мікроушкоджень при псоріазі, мікротріщин і екскоріацій при алергодерматозах, ерозивних поверхонь при пухирних дерматозах сприяють появі агресивніших ізолятів з вираженим патогенним потенціалом, що в результаті призводить до обтяження перебігу основного захворювання. Так, при проведенні досліджень щодо сумісного культивування штамів з високим патогенним потенціалом встановлено, що S. haemolyticus посилює гемолітичну активність $S$. aureus у $66,7 \%$ випадків.

3 метою підвищення терапевтичної ефективності та нормалізації мікробіоценозу хворих на хронічні дерматози в комплексному лікуванні використовували зовнішню терапію, що полягала у використанні мазі з протимікробними властивостями, що містить мупіроцин, 2-3 рази на день. Препарат належить до антибіотиків особливого класу, що не має перехресної резистентності й виявляє високу активність щодо стафілококів, пригнічує синтез бактеріальних протеїназ, зберігає низьку активність щодо нормальної мікрофлори (Corynebacterium spp.).

У дослідження було залучено хворих на тяжкі форми дерматозів з підвищеним ризиком розвитку інфекційних ускладнень, які були пов’язані зі зниженням активності специфічних і неспецифічних механізмів захисту та підвищенням бактеріального обсіменіння шкіри, підвищенням патогенності мікрофлори, а також неодноразовим використанням антибактеріальних засобів, що обумовлювало зниження чутливості до них.

Під час оцінки результатів зовнішньої терапії з використанням мупіроцину було продемонстровано зменшення ризику розвитку піококових ускладнень за рахунок зниження загального обсіменіння шкіри на 1-2 порядки за майже повної відсутності агресивних штамів $S$. aureus i $S$. haemolyticus та відновлення 


\section{КЛІНІЧНІ СПОСТЕРЕЖЕННЯ}

нормального мікробного пейзажу шкіри з переважанням коменсального виду $S$. epidermidis.

У результаті використання зазначеної схеми зовнішнього лікування хворих на тяжкі хронічні алергічні дерматози в період загострення відмічено регрес клінічних ознак піококової інфекції у 94,2\% осіб. Клінічну ремісію досягнуто у 18,9\% хворих, значне поліпшення - у 53,9\%, поліпшення - у 11,4\% (рис. 7). Таким чином, використання топічних препаратів антимікробної дії в разі розвитку бактеріальних ускладнень тяжких хронічних дерматозів з наявністю патогенетично значимої піококової інфекції є високоефективним.

\section{Висновки}

Розроблений метод топічного лікування мупіроцином є високоефективним засобом лікування хворих на тяжкі хронічні дерматози, які в комплексному лікуванні одержують імуносупресивну терапію. Враховуючи профіль ефективності та безпечності препарату, що їх було продемонстровано як в ході клінічних досліджень, так і в рамках зазначеної роботи,

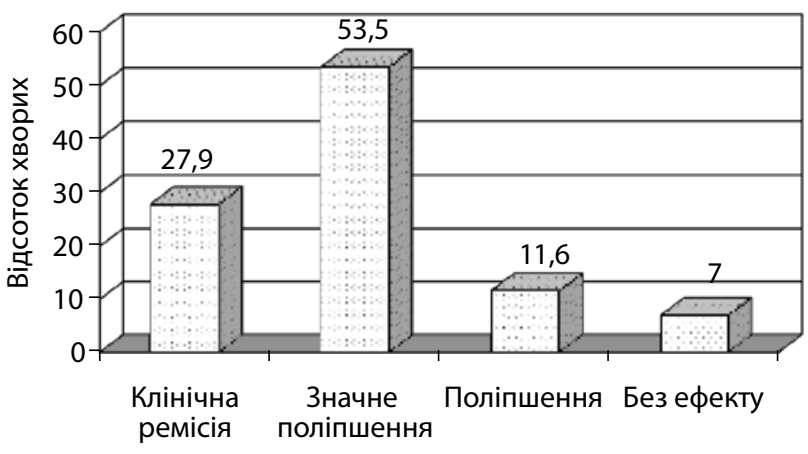

Рис. 7. Терапевтична ефективність зовнішньої терапії з використанням мазі мупіроцину

мупіроцин може претендувати на місце в стандартах лікування поряд з іншими ефективними антибактеріальними препаратами та може бути рекомендований до ширшого застосування.

В сучасному арсеналі українських дерматологів з'явився перпарат мупіроцину - Бактопік у формі мазі 2\%, виробництва Кусум Хелтхкер Пвт Лтд.

\section{Список літератури}

1. Бактериальные инфекции кожи и их значение в клинической практике дерматолога /
С.А. Масюкова, В.В. Гладько, М.В. Устинов и др. Consilium medicum. 2004. Т. 6, № 3. С. 180 185.

2. Диференційований підхід до діагностики та зовнішньої терапії екземи 2018. № 1 (79). С. 50-55.

3. Кукушкин Г.В., Старостина Е.Г. Инфекции у больных сахарным диабетом (лекция). РМЖ. 2016. № 20. С. 1327-1333.

4. Нобл У.К., Рыбалка В.М. Микробиология кожи человека. Монография. М.: Медицина,

986. 496 c.

5. Приказ МЗ СССР № 535 от 22.04.1985 «Об унификации микробиологических (бактериологических) методов исследования, применяемых в клинико-диагностических лабора-

ориях лечебно-профилактических учреждений

6. Сравнительная эффективность $0,75 \%$ мази хлорамфеникола и $2 \%$ мази мупироцина при лечении в амбулаторных условиях взрослых пациентов с инфекциями кожи и мягких тканей / Ю.А. Белькова, Л.С. Страчунский, О.И. Кречикова и др. Клиническая микробиолоия и антимикробная химиотерапия. 2007. Т. 9, № 1. С. 57-65.

7. A comparison of the efficacy and safety of mupirocin cream and cephalexin in the treatment of secondarily infected eczema / T. Rist, L.C. Parish, L.R. Capin et al. Clin Exp Dermato 002. Vol. 27, Iss. 1. P. 14-20.

8. Booth J.H., Benrimoj S.I. Mupirocin in the treatment of impetigo. Int. J. Dermatol. 1992. Vol. 31, No. 1. P. 1-9

9. BradleyS.F. Effectiveness of mupirocin in the control of methicillin-resistant Staphylococcus aureus. Infect. Med. 1993. Vol. 10. P. 23-31.

10. Chain E. B., Mellows G. Pseudomonic acid. Part I. The structure of pseudomonic acid A, a novel antibiotic produced by Pseudomonas fluorescens. J. Chem. Soc. Perkin Transactions 1977. Vol. 1. P. 294-309.

11. D'souza A.A., Shegokar R. Polyethylene glycol (PEG): A versatile polymer for pharmaceucal applications. Expert Opinion on Drug Delivery. 2016. Vol. 13, Iss. 9. P. 1257-1275.

12. Dux P.H., Fields L., Pollock D. $2 \%$ topical mupirocin versus systemic erythromycin and cloxacillin in primary and secondary skin infections. Curr Ther Res. 1986. Vol. 40. P. 933-940.
13. Edge R., Argáez C. Topical antibiotics for impetigo: a review of the clinical effectiveness 13. Edge R., Argáez C. Topical antibiotics

and guidelines. Ottawa: CADTH, 2017. $21 \mathrm{p}$.
14. Gould J.C., Smith J.H., Moncur H. Mupirocin in general practice: a placebo-controlled 14. Gould J.C., Smith J.H., Moncur H. Mupirocin in general practice: a placebo-controlled
trial. Wilkinson D.S. Price J.D., eds. Mupirocin - a novel topical antibiotic. London: Royal Society trial. Wilkinson D.S., Price J.D., eds. Mupirocin - a novel topical antibiotic. London: Roy
of Medicine International Congress and Symposium Series. 1984. No. 80. P. 85-93

15. Gratton D. Topical mupirocin versus oral erythromycin in the treatment of primary and econdary skin infections. Int J Dermatol. 1987. Vol. 26. P. 472-473.

16. Hughes J., Mellows G. Inhibition of isoleuciyl transfer ribonucleic acid synthetase Escherichia coli by pseudomonic acid. Biochem. J. 1978. Vol. 176. P. 305-318.

17. Hughes J., Mellows $\mathrm{G}$. On the mode of action of pseudomonic acid: inhibition of protein synthesis in Staphylococcus aureus. J. Antibiot. 1978. Vol. 31. P. 330-335.

18. Interventions for impetigo / S. Koning, R. vander Sande, A.P. Verhagen et al. Cochrane Database of Systematic Reviews. 2012. Iss. 1. Art. No.: CD003261. DOI: 10.1002/14651858.

19. Kennedy C.T.C., Watts J.A., Speller D.C.E. Mupirocin in the treatment of impetigo: a controlled trial against neomycin. Wilkinson D.S., Price J.D., eds. Mupirocin - a novel topical antibiotic. London: Royal Society of Medicine International Congress and Symposium Series. 1984 biotic. London:
No. 80. P. 79

20. McLinn S. Topical mupirocin vs. systemic erythromycin treatment for pyoderma. Paediatr Infect Dis J. 1988. Vol. 7. P. $785-790$

21. Pappa K A. The clinical development of mupirocin. J.Amer. Acad. Dermatol. 1990. Vol. 22. P. 873-879

22. Pseudomonic acid: an antibiotic produced by Pseudomonas fluorescens / A.T. Fuller, G. Mellows, M. Woodford et al. Nature. 1971. Vol. 234. P. 416-417.

23. Staphylococcus aureus prophylaxis in hemodialysis patients using central venous catheter, effect of mupirocin ointment / R. Sesso, D. Barbosa, IL Leme et al. J. Amer. Soc. Nephrol. 1998. Vol. 9, Iss. 6. P. 1085-1092.

24. Trilla A., Miro J.M. Identifying high-risk patients for Staphylococcus aureus infections: skin and soft tissue infections. J Chemother. 1995. Vol. 7. P. 27-33.

\section{References}

1. Masyukova SA, Glad'ko VV, Ustinov MV, et al. Bakterial'nye infektsii kozhi i ikh znachenie $\checkmark$ klinicheskoy praktike dermatologa [Bacterial skin infections and their significance in the clinical practice of a dermatologist]. Consilium medicum. 2004;6(3):180-185.

2. Kutasevich YaF, Ishcheykin KE, Zyuban IV, Mangusheva VYu. Diferentsiyovaniy pidkhid do diagnostiki ta zovnishn'oi terapii ekzemi [Differentiated approach to the diagnosis and external therapy of eczema]. Dermatologiya ta venerologiya. 2018;1(79):50-55.

3. Kukushkin GV, Starostina EG. Infektsii u bol'nykh sakharnym diabetom (lektsiya) (Infection in patients with diabetes mellitus (lecture). RMZh. 2016;20:1327-1333.

4. NobI UK, Rybalka VM. Mikrobiologiya kozhi cheloveka monografiya [Microbiology of hu-

man skin. Monograph]. Moscow: Meditsina, 1986.496 p.
5. Prikaz MZ SSSR № 535 ot 22.04 .1985 «Ob unifikatsii mikrobiologicheskikh (bakteriologicheskikh) metodov issledovaniya, primenyaemykh $v$ kliniko-diagnosticheskikh laboratoriyakh lechebno-profilakticheskikh uchrezhdeniy" [The order of the Ministry of Health of the USSR No. 535 dated 04/22/1985 "On the unification of microbiological (bacteriological) research methods used in clinical diagnostic laboratories of medical institutions"].

6. Bel'kova YuA, Strachunskiy LS, Krechikova OI, et al. Sravnitel'naya effektivnost' $0,75 \%$ maz khloramfenikola i $2 \%$ mazi mupirotsina pri lechenii v ambulatornykh usloviyakh vzroslykh patsiento $s$ infektsiyami kozhi i myagkikh tkaney [Comparative efficacy of $0.75 \%$ chloramphenicol ointment and $2 \%$ mupirocin ointment in outpatient treatment of adult patients with infections of the skin and soft tissues]. Klinicheskaya mikrobiologiya i antimikrobnaya khimioterapiya. 2007;9(1):57-65.

7. Rist T, Parish LC, Capin LR, et al. A comparison of the efficacy and safety of mupirocin cream and cephalexin in the treatment of secondarily infected eczema. Clin Exp Dermatol. 2002;27(1):14-20.

8. Booth JH, Benrimoj SI. Mupirocin in the treatment of impetigo. Int. J. Dermatol. 992;31(1):1-9.

9. Bradley SF. Effectiveness of mupirocin in the control of methicillin-resistant Staphylococcus aureus. Infect. Med. 1993;10:23-31.

10. Chain EB, Mellows G. Pseudomonic acid. Part I. The structure of pseudomonic acid A a novel antibiotic produced by Pseudomonas fluorescens. J. Chem. Soc. Perkin Transactions.

11. D'souza AA, Shegokar R. Polyethylene glycol (PEG): A versatile polymer for pharmaceual applications. Expert Opinion on Drug Delivery. 2016;13(9):1257-1275

12. Dux PH, Fields L, Pollock D. $2 \%$ topical mupirocin versus systemic erythromycin and clox(19.

13. Edge R, Argáez C. Topical antibiotics for impetigo: a review of the clinical effectiveness and guidelines. Ottawa: CADTH, 2017. $21 \mathrm{p}$

14. Gould JC, Smith JH, Moncur H. Mupirocin in general practice: a placebo-controlled trial. Wikinson DS, Price JD, eds. Mupirocin - a novel topical antibiotic. Lon 15. Grat

15. Gratton D. Topical mupirocin versus oral erythromycin in the treatment of primary and

16. Hughes J, Mellows G. Inhibition of isoleuciyl transfer ribonucleic acid synthetase

17. Hughes J, Mellows G. On the mode of action of pseudomonic acid: inhibition of protein 1:330-335.

18. Koning S, R vander Sande, Verhagen AP, et al. Interventions for impetigo. Cochrane Database of Systematic Reviews. 2012. Iss. 1. Art. No.: CD003261. DOI: 10.1002/14651858. D003261.pub3.

19. Kennedy CTC, Watts JA, Speller DCE. Mupirocin in the treatment of impetigo: a controlled trial against neomycin. Wilkinson DS, Price JD, eds. Mupirocin - a novel topical antibiotic. London: Royal Society of Medicine International Congress and Symposium Series. 1984;80:79.

20. McLinn S. Topical mupirocin vs. systemic erythromycin treatment for pyoderma. Paediatr Infect Dis J. 1988:7:785-790.

21. Pappa KA. The clinical development of mupirocin. J. Amer. Acad. Dermatol. 1990;22:873-

22. Fuller AT, Mellows G, Woodford M et al. Pseudomonic acid: an antibiotic produced by Pseudomonas fluorescens. Nature. 1971;234:416-417.

23. Sesso R, Barbosa D, Leme IL, et al. Staphylococcus aureus prophylaxis in hemodialysis patients using central venous catheter, effect of mupirocin ointment. J. Amer. Soc. Nephrol. 1998;9(6): 1085-1092.

24. Trilla A, Miro JM. Identifying high-risk patients for Staphylococcus aureus infections: skin and soft tissue infections. J Chemother. 1995;7:27-33. 


\title{
НАРУЖНАЯ АНТИБАКТЕРИАЛЬНАЯ ТЕРАПИЯ: СОВРЕМЕННЫЕ ВОЗМОЖНОСТИ ЛЕЧЕНИЯ
}

Я.Ф. Кутасевич, С.К. Джораева, О.И. Олейник, Г.М. Беляев

ГУ «Институт дерматологии и венерологии НАМН Украины»

Резюме

Цель работы - изложить принципы и улучшить антибиотикотерапию пиококковых инфекций кожи и мягких тканей.

Материалы и методы. В исследование были включены 52 пациента с тяжелыми и распространенными дерматозами, находившихся на стационарном лечении в дерматологическом отделении ГУ «ИДВ НАМН Украины». Идентификацию аэробных грамположительных, аэробных грамотрицательных ферментирующих и неферментирующих бактерий, выделенных из разных участков кожи, проводили с помощью рутинных методов на основании морфологических, культуральных и биохимических свойств возбудителей.

Результаты. В результате бактериологического исследования было выделено 59 штаммов микроорганизмов от пациентов. Доминировали микроорганизмы рода Staphylococcus, утяжелявшие течение дерматозов. С целью повышения терапевтической эффективности и нормализации микробиоценоза больных хроническими дерматозами в лечении использовали наружную терапию, включавшую мазь мупироцина. В результате использования указанной схемы наружного лечения больных тяжелыми хроническими аллергическими дерматозами в период обострения отмечен регресс клинических признаков пиококковой инфекции у 94,2 \% пациентов. Клиническая ремиссия достигнута у 28,9\% больных, значительное улучшение у $53,9 \%$, улучшение - у $11,4 \%$.

Выводы. Изучены возможности использования топических антибактериальных средств, механизм действия, фармакокинетика и целесообразность применения мупироцина в практике врача-дерматолога, что позволяет рекомендовать мупироцин для лечения пациентов с хроническими дерматозами, длительно получавших иммуносупрессивную терапию.

Ключевые слова: наружная терапия, антибактериальная терапия, мупироцин.

\section{EXTERNAL ANTIBIOTIC THERAPY: MODERN TREATMENT OPTIONS}

\author{
Ya.F. Kutasevych, S.K. Dzhoraeva, O.I. Oliinyk, G.M. Biliaev
}

SE «Institute of Dermatology and Venereology of NAMS of Ukraine»

\section{Abstract}

The objective of the work is to set out the principles and improve the antibiotic treatment of pococcal infections of the skin and soft tissues.

Materials and methods. The study included 43 patients with severe and widespread dermatoses who were hospitalized in the dermatology department of the SE "IDV NAMS of Ukraine". The identification of aerobic gram-positive, aerobic gram-negative fermenting and non-fermentative bacteria isolated from different skin areas was performed using routine methods based on the morphological, cultural, and biochemical properties of the pathogens.

Results and discussion. As a result of bacteriological examination, 59 strains of microorganisms were isolated from patients. Microorganisms of the genus Staphylococcus, which weighed down the course of dermatoses, dominated. In order to increase the therapeutic efficacy and normalize the microbiocenosis of patients with chronic dermatoses, external therapy was used in the treatment, which included mupirocin ointment. As a result of the use of this external treatment scheme for patients with severe chronic allergic dermatoses during the period of exacerbation, there was a regression of the clinical signs of picococcal infection in $94.2 \%$ of patients. Clinical remission was achieved in $28.9 \%$ of patients, a significant improvement in $53.9 \%$, improvement in $11.4 \%$.

Conclusions. The possibilities of using topical antibacterial agents, the mechanism of action, pharmacokinetics and the expediency of using mupirocin in the practice of a dermatologist have been studied, which allows us to recommend mupirocin for the treatment of patients with chronic dermatoses who have received immunosuppressive therapy for a long time.

Key words: external therapy, antibacterial therapy, mupirocin.

Відомості про авторів:

Кутасевич Яніна Францівна - д-р мед. наук, професор, директор ДУ «/нститут дерматології та венерології НАМН України». ORCID ID: https://orcid.org/0000-0001-8706-1487.

Джораєва Світлана Карьягдиївна - канд. мед. наук, зав. лабораторії мікробіології ду «/нститут дерматології та венерології НАМН України».

ORCID ID: https://orcid.org/0000-0003-2486-5474

Олійник Ольга Іванівна - аспірант відділу дерматології, інфекційних та паразитарних захворювань шкіри ду «Інститут дерматології та венерології НАМН України».

ORCID ID: https://orcid.org/0000-0002-6408-830X.

Біляєв Георгій Митрофанович - д-р мед. наук, старший науковий співробітник відділу дерматології, інфекційних та паразитарних захворювань шкіри Ду «Інститут дерматології та венерології НАМН України». 